\title{
ANALIZA PORÓWNAWCZA TEMPERATURY POWIERZCHNIOWEJ PRZEGRÓD W LOKALACH MIESZKALNYCH W BUDYNKU WIELORODZINNYM Z WIELKIEJ PLYTY
}

\author{
Konrad Podawca ${ }^{凶}$
}

Wydział Budownictwa i Inżynierii Środowiska, Szkoła Główna Gospodarstwa Wiejskiego w Warszawie, Warszawa

\begin{abstract}
STRESZCZENIE
W artykule przedstawiono badania temperatury emitowanej przez przegrody budowlane w wielorodzinnym budynku zrealizowanym w technologii wielkiej płyty. Do badań wytypowano dwa lokale mieszkalne o takim samym układzie funkcjonalnym, ale innym położeniu w bryle obiektu. Dokonane pomiary ukazały znaczące różnice temperatury, szczególnie w newralgicznych miejscach, pomiędzy mieszkaniem środkowym na I piętrze a lokalem mieszkalnym szczytowym na ostatniej kondygnacji. Wykonana analiza jednoznacznie wykazała konieczność termomodernizacji obiektów z wielkiej płyty, jak również znaczące różnice w uzyskaniu komfortu cieplnego w lokalach mieszkalnych położonych na różnych kondygnacjach i posiadających lub nie ściany szczytowe.
\end{abstract}

Słowa kluczowe: wielorodzinny budynek mieszkalny, termowizja, wielka płyta, komfort cieplny

\section{WSTĘP}

Budynki z wielkiej płyty są obiektem badań od wielu lat, a szczególnie od momentu, w którym pojawiły się opinie, że były projektowane $\mathrm{z}$ założeniem ich eksploatacji na okres 50 lat. Ten pogląd jest całkowicie nieprawdziwy, co zostało uzasadnione m.in. w pracach Instytutu Techniki Budowlanej (Runkiewicz, Szudrowicz, Geryło, Szulc i Sieczkowski, 2014) czy innych autorów (Ostańska, 2016).

Problemy związane $\mathrm{z}$ budynkami wykonanymi $\mathrm{w}$ technologii wielkopłytowej są przedmiotem badań i dyskusji środowiska naukowców i praktyków, m.in. w ramach cyklicznej konferencji naukowo-technicznej „Awarie budowlane” (Wójtowicz, 2011; Alsabry, Mrówczyńska, Bazan-Krzywoszańska i Skiba, 2016; Knyziak, 2017).

Większość autorów jest zgodna co do wad związanych tak z wykonaniem obiektów z wielkiej płyty, jak i eksploatacji tego typu budynków. Już w pierwszych latach ich użytkowania zaczęły ujawniać się błędy wykonawcze. Za najczęstsze objawy błędów w budynkach z wielkiej płyty uznaje się (Sawicki, 2007; Wójtowicz, 2011; Sobczak-Piąstka i Podhorecki, 2014; Alsabry i in., 2016; Knyziak 2017):

- rysy poziome w złączu poziomym między ściana a stropem, spowodowane różnicą temperatury nad i pod stropem, występujące tak na powierzchni zewnętrznej, jak i wewnętrznej ścian;

- zawilgocenie ścian szczytowych;

- kondensację pary wodnej w okolicach wylotów kanałów wentylacji stropodachów;

- uszkodzenia i zawilgocenia płyt balkonowych oraz ścian piwnic;

- złe wykonanie samych prefabrykatów ścian zewnętrznych (odpadanie warstwy fakturowej, zarysowania i spękania, przecieki wód opadowych przez fakturę, nadmierne zawilgocenia, przemarzanie);

${ }^{凶}$ konrad_podawca@sggw.pl 
Podawca, K. (2018). Analiza porównawcza temperatury powierzchniowej przegród w lokalach mieszkalnych w budynku wielorodzinnym z wielkiej płyty. Acta Sci. Pol. Architectura, 17 (1), 35-44. doi: 10.22630/ASPA.2018.17.1.4

- złe mocowanie i zła izolacja przed wilgocią i woda warstwy ocieplającej (obniżenie cech izolacyjnych wynikające z zawilgocenia lub/i zmiany struktury materiału termoizolacyjnego, odspajanie się tej warstwy od innych warstw ściany);

- nieprawidłowe łączenie elementów prefabrykowanych oraz zbyt duże spoiny, bez uszczelnienia (klawiszowanie stropu, nieszczelności, korozja stali, źle uszczelniona dylatacja).

Rosnące koszty ogrzewania, niszcząca się elewacja czy zsunięta, zawilgocona warstwa wełny mineralnej powodowały, że od pewnego czasu administratorzy takich budynków podjęli działania termomodernizacyjne i rewitalizacyjne. Spółdzielnie mieszkaniowe, korzystając $\mathrm{z}$ pomocy państwa, rozpoczęły już w 1982 roku ocieplanie wielu budynków lub przynajmniej ich ścian szczytowych. Do 1997 roku był to wynik funkcjonujących dotacji dla spółdzielni na usuwanie wad technologicznych. Niestety stosowana grubość izolacji była 2-3 razy mniejsza od obecnych wymagań ochrony cieplnej budynków. Małe grubości zastosowanych w pierwszych dociepleniach warstw styropianu lub wełny mineralnej sprawiły, że wiele z ocenianych budynków zostało docieplonych już dwukrotnie. Opłacalność dociepleń i modernizacji instalacji c.o. budynków w Warszawie, ale i w wielu polskich miastach jest dyskusyjna. Prace modernizacyjne tylko częściowo przekładają się na oszczędności wykazane w projektach dociepleń. $Z$ jednej strony wynika to ze złych nawyków mieszkańców i nieumiejętności oszczędzania ciepła. Z drugiej strony tzw. pozytywne zachowania użytkowników, prowadzące do mniejszego wykorzystania energii, odbywają się często kosztem komfortu cieplnego i jakości powietrza w pomieszczeniach (Runkiewicz i in., 2014).

Zwraca się uwagę na poważne problemy dotyczące diagnozowania oraz napraw, modernizacji i przystosowania takich obiektów do aktualnych standardów (Runkiewicz i in., 2014). Często wynika to z faktu braku kompleksowych badań, analiz i statystyk, z których wynikałoby, które budynki znajdują się w dobrym lub złym stanie technicznym (Sobczak-Piąstka i Podhorecki, 2014), oraz jednoznacznych metod oceny obiektów mieszkalnych. Jeżeli nawet takie przeglądy były robione, to ich wyniki wskazywały, że w wielu nieocieplonych budynkach z lat 80-90. XX wieku przemarzanie i zagrzybienie wciąż występuje (Knyziak, 2017).
W niedogrzanych mieszkaniach, szczególnie w miejscach zasłoniętych meblami, wilgoć utrzymywała się długo, co potęgowało problemy mykologiczne.

Poczucie komfortu cieplnego dla człowieka, rozumianego jako stan, w którym organizm ma wrażenie zrównoważonego bilansu energetycznego, jest bardzo ważne. Do czynników wpływających na ten komfort w ujęciu lokalnym można zaliczyć: ciepło wytworzone przez człowieka, typ i izolacyjność odzieży oraz rodzaj wykonywanej aktywności fizycznej, prędkość przepływu powietrza, wilgotność powietrza oraz temperaturę powierzchni przegród budowlanych (Sudoł-Szopińska i Chojnacka, 2007; Bohojło, 2010). W artykule skupiono się jedynie na ostatnim czynniku, który w zestawieniu z temperaturą powietrza może dać odpowiedź na pozytywne lub negatywne oddziaływanie przegród na odczucia termiczne mieszkańców.

\section{CEL I ZAKRES BADAŃ}

Celem badań była ocena warunków termicznych przegród tworzacych lokale mieszkalne zlokalizowane w budynku wielorodzinnym zrealizowanym $\mathrm{w}$ technologii wielkiej płyty. Wykonane pomiary i analiza porównawcza doprowadziły do:

- ukazania różnic w warunkach cieplnych pomiędzy mieszkaniami zlokalizowanymi na drugiej i ostatniej kondygnacji w budynkach z wielkiej płyty, zrealizowanych w latach 1980-1982;

- identyfikacji miejsc występowania ubytków ciepła w analizowanych lokalach, wskazujących na błędy wykonawcze budynku z wielkiej płyty;

- określenia odczuwania komfortu cieplnego, wynikającego z temperatury powietrza oraz temperatury przegród w mieszkaniach objętych badaniami;

- uzasadnienia celowości docieplenia ścian szczytowych i stropodachu w budynkach z wielkiej płyty.

Zakres badań obejmował:

- wytypowanie obiektów analizy na podstawie następujących cech: technologia budynku - wielka płyta, funkcja lokalu - mieszkalna, taki sam układ funkcjonalny pomieszczeń, zróżnicowane położenie obiektów badań w bryle budynku;

- wykonanie pomiarów powierzchniowych temperatury przegród $\mathrm{z}$ uwzględnieniem ich rodzaju i lokalizacji (ściana zewnętrzna, ściana wewnętrzna, strop, pokój, kuchnia, łazienka); 
Podawca, K. (2018). Analiza porównawcza temperatury powierzchniowej przegród w lokalach mieszkalnych w budynku wielorodzinnym z wielkiej płyty. Acta Sci. Pol. Architectura, 17 (1), 35-44. doi: 10.22630/ASPA.2018.17.1.4

- interpretację wyników badań w kontekście technologicznym - miejsc newralgicznych w lokalach w budynku z wielkiej płyty, jak również w aspekcie odczuwania komfortu cieplnego mieszkańców danych lokali.

\section{MATERIA I METODY}

Obiektami badań były dwa lokale mieszkalne 3-pokojowe, o powierzchni około $62 \mathrm{~m}^{2}$, położone na warszawskich Jelonkach:

- obiekt I, mieszkanie szczytowe, położone na III piętrze w 4-kondygnacyjnym wielorodzinnym budynku zlokalizowanym na działce $\mathrm{nr} 3 / 8 \mathrm{z}$ obrębu 6-11-12 przy ulicy Karabeli 9, usytuowane w układzie północ - południe;

- obiekt II, mieszkanie środkowe, usytuowane na I piętrze w 4-kondygnacyjnym wielorodzinnym budynku, poddanym w 2017 roku termomodernizacji, zlokalizowanym na działce $\mathrm{nr} 3 / 36 \mathrm{z}$ obrębu 6-11-12 przy ulicy Lazurowej 18, usytuowane w układzie północ - południe.

Podstawą badań była analiza termowizyjna, będąca metodą badawczą polegającą na zdalnej i bezdotykowej ocenie rozkładu temperatury na powierzchni badanego ciała. Metoda ta jest oparta na obserwacji i zapisie rozkładu promieniowania podczerwonego wysyłanego przez każde ciało, którego temperatura jest wyższa od zera bezwzględnego, i przekształceniu tego promieniowania na światło widzialne. Do uzyskania termogramów przedstawiających pole temperatury na powierzchni wykorzystano kamerę termowizyjną FLUKE Ti100 wraz z pomocniczym sprzętem kamerą Flir C-2. Przeprowadzone pomiary uwzględniały zapisy normy PN-EN 13187:2001 (Właściwości cieplne budynku-jakościowa detekcja wad cieplnych w obudowie budynku. Metoda podczerwieni) oraz wskazówki zawarte w fachowej literaturze (Rymarczyk, Dzierzgowski i Strzeszewski, 2005; Kukla, 2015).

Badania przeprowadzono od wewnątrz lokalu mieszkalnego, przy $\varepsilon=0,95$, w następujących terminach i warunkach:

- w obiekcie I: dnia 14 stycznia 2018 roku w godz. 15-16, przy temperaturze wewnętrznej równej około $20,5^{\circ} \mathrm{C}$ i wilgotności około $49 \%$, na zewnątrz panowała temperatura $-5,5^{\circ} \mathrm{C}$, wilgotność względna $81 \%$, zachmurzenie całkowite, brak opadów i wiatr $18 \mathrm{~km} \cdot \mathrm{h}^{-1} \mathrm{SSE}$;
- w obiekcie II: dnia 15 stycznia 2018 roku w godz. 15.30-16.30, przy temperaturze wewnętrznej równej około $20,4^{\circ} \mathrm{C}$ i wilgotności około $43 \%$, na zewnątrz panowała temperatura $-5,5^{\circ} \mathrm{C}$, wilgotność względna $72 \%$, zachmurzenie duże, brak opadów i wiatr $17 \mathrm{~km} \cdot \mathrm{h}^{-1} \mathrm{SSE}$.

Warunki w czasie pomiarów panujące w układach obiekt I - obiekt II, jak również pomieszczenie - otoczenie zewnętrzne dają podstawy do uznania wykonanych badań za miarodajne do dokonania porównań.

Na etapie interpretacji wyników wykorzystano podstawy z zakresu fizyki budowli (Alsabry, 2010; Dylla, 2015; Kaliszuk-Wietecka, 2017) oparte na normie PN-EN ISO 6946:2008, z wykorzystaniem oprogramowania ArCadia Termo, oraz oceny komfortu cieplnego z wykorzystaniem wykresu Königa, ukazującego zależność temperatury powietrza i otaczających płaszczyzn przegród budowlanych w odniesieniu do odczuwanego przez człowieka wrażenia chłodu czy gorąca. W kontekście porównawczym zastosowano pojedyncze wyniki otrzymane z kamery termowizyjnej odniesione do temperatury pomieszczeń i konkretnych miejsc pomiarowych w postaci różnic temperatury:

$-\Delta T_{\mathrm{I}(\mathrm{II})}=t_{p}-t_{o}\left[{ }^{\circ} \mathrm{C}\right]$

gdzie: $t_{p}-$ temperatura przegrody $\mathrm{w}$ danym punkcie, $t_{o}$ - średnia temperatura powietrza w pomieszczeniu;

$-\Delta T_{R}=\Delta T_{\mathrm{I}}-\Delta T_{\mathrm{II}}\left[{ }^{\circ} \mathrm{C}\right]$

gdzie: $\Delta T_{\mathrm{IIII}}$ - różnice temperatury $\mathrm{w}$ analogicznych miejscach przegród w obiektach badań.

\section{WYNIKI}

Miejsca dokonania pomiarów są przedstawione na rysunku 1 i są analogiczne dla obydwu obiektów badań. Określone wartości temperatury są wynikiem badania uzyskanego z punktowego pomiaru kamerą termowizyjną (tab. 1).

Wykonane badania zobrazowano również przykładowymi termogramami, które zestawiono w odniesieniu do tych samych lokalizacji w układzie funkcjonalnym analizowanych lokali mieszkalnych.

Jedynym miejscem, które ma obniżone właściwości termiczne w obu lokalach jest ściana wnękowa 
Podawca, K. (2018). Analiza porównawcza temperatury powierzchniowej przegród w lokalach mieszkalnych w budynku wielorodzinnym z wielkiej płyty. Acta Sci. Pol. Architectura, 17 (1), 35-44. doi: 10.22630/ASPA.2018.17.1.4

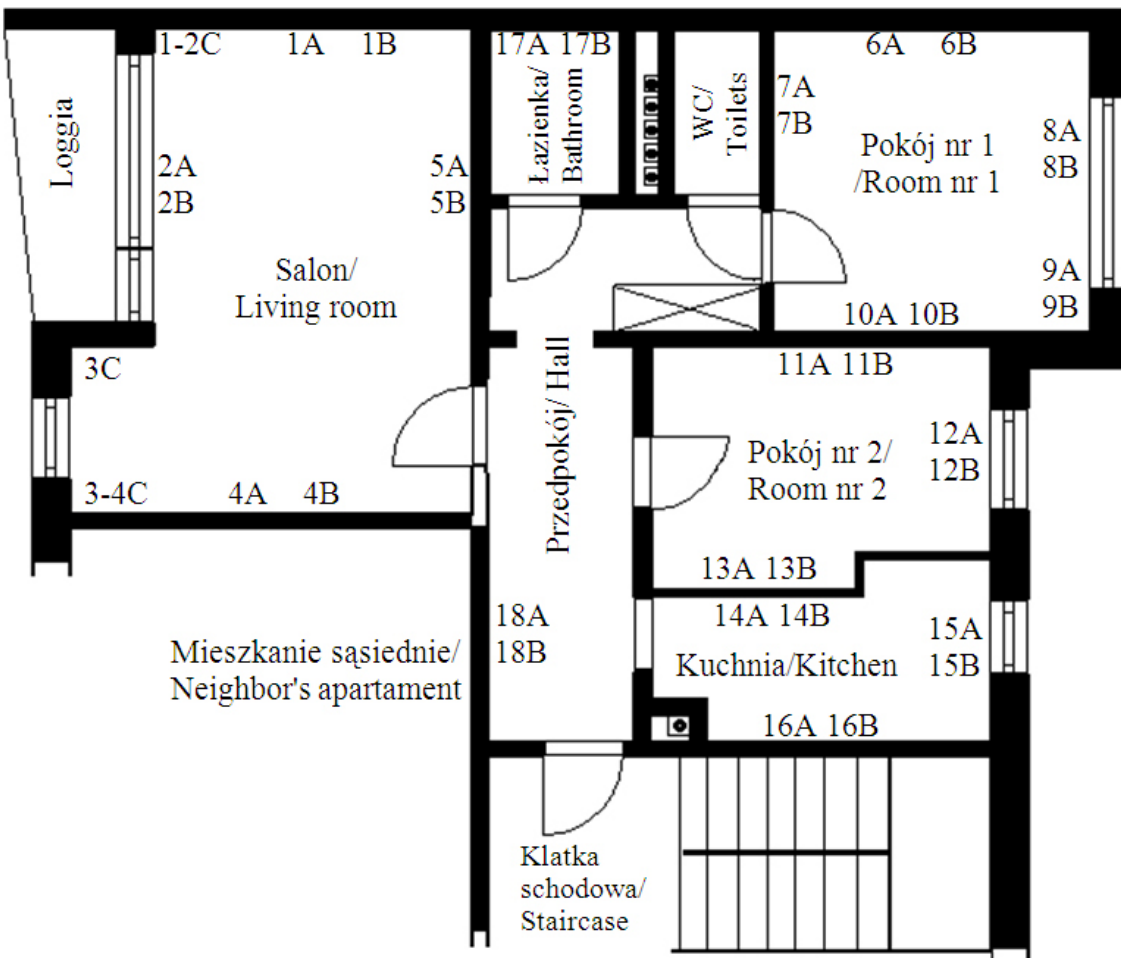

Rys. 1. Układ funkcjonalny lokalu mieszkalnego oraz schemat punktów pomiarów zgodnie z tabelą 1 (opr. autora)

Fig. 1. Functional layout of a dwelling and diagram of measurement points in accordance with Table 1 (by the authors)

Tabela 1. Wyniki pomiarów temperatury przegród w badanych lokalach mieszkalnych

Table 1. Results of measurements of baffle temperatures in the analyzed dwellings

\begin{tabular}{|c|c|c|c|c|c|}
\hline \multirow{2}{*}{$\begin{array}{l}\mathrm{Nr} \\
\mathrm{No}\end{array}$} & \multirow{2}{*}{$\begin{array}{l}\text { Rodzaj pomieszczenia } \\
\text { Type of room } \\
\begin{array}{l}\text { Miejsce pomiaru } \\
\text { Place of measurement }\end{array}\end{array}$} & \multicolumn{2}{|c|}{ Uwagi-Comments } & \multicolumn{2}{|c|}{$\begin{array}{l}\text { Temperatura }\left[{ }^{\circ} \mathrm{C}\right] \\
\text { Temperature }\end{array}$} \\
\hline & & Obiekt I - Object I & Obiekt II - Object II & $\begin{array}{l}\text { Obiekt I } \\
\text { Object I }\end{array}$ & $\begin{array}{l}\text { Obiekt II } \\
\text { Object II }\end{array}$ \\
\hline & Salon - Living room & Warunki wewnętrz & e-Inside condition & 20,5 & 20,4 \\
\hline $1 \mathrm{~A}$ & płaszczyzna ściany - wall plane & \multirow{2}{*}{$\begin{array}{l}\text { zewn. - outside } \\
\text { zach. - west. }\end{array}$} & \multirow{2}{*}{ wewn. - inside } & 20,0 & 21,6 \\
\hline 1B & krawędź ściana-strop - wall-ceiling edge & & & 15,5 & 21,5 \\
\hline $1-2 \mathrm{C}$ & $\begin{array}{l}\text { naroże ścian i stropu } \\
\text { corner wall-ceiling }\end{array}$ & $\begin{array}{l}\text { zewn.- zewn.-stropodach } \\
\text { out.-in.-flat roof }\end{array}$ & $\begin{array}{l}\text { wewn.-zewn.-strop } \\
\text { in.-out.- ceiling }\end{array}$ & 12,8 & 22,3 \\
\hline $2 \mathrm{~A}$ & ściana balkonowa - balcony wall & \multicolumn{2}{|c|}{ zewn. - outside, płd. - south., okna - windows } & 19,4 & 21,0 \\
\hline $2 \mathrm{~B}$ & $\begin{array}{l}\text { krawędź okno-strop - window-ceiling } \\
\text { edge }\end{array}$ & \multicolumn{2}{|c|}{$\begin{array}{l}\text { rama okna bezpośrednio pod stropem - window frame } \\
\text { directly under the ceiling }\end{array}$} & 10,5 & 20,6 \\
\hline $3 \mathrm{C}$ & naroże ściana loggi - corner wall loggia & $\begin{array}{l}\text { zewn. - outside, wsch. - east } \\
\text { loggia otwarta - open log. }\end{array}$ & $\begin{array}{l}\text { zewn. - outside, zach - west., } \\
\text { loggia zab. - log. built-up }\end{array}$ & 11,8 & 12,1 \\
\hline $3-4 \mathrm{C}$ & $\begin{array}{l}\text { naroże ścian i stropu } \\
\text { corner wall-ceiling }\end{array}$ & $\begin{array}{l}\text { zewn.-wewn.-stropodach } \\
\text { out.-in.-flat roof }\end{array}$ & $\begin{array}{l}\text { zewn.-wewn.-strop } \\
\text { out.-in.-ceiling }\end{array}$ & 11,0 & 26,4 \\
\hline $4 \mathrm{~A}$ & płaszczyzna ściany - wall plane & \multirow{2}{*}{\multicolumn{2}{|c|}{$\begin{array}{c}\text { wewn. }- \text { inside, } \\
\text { międzylokalowa }- \text { between apartments }\end{array}$}} & 20,0 & 21,5 \\
\hline 4B & krawędź ściana-strop - wall-ceiling edge & & & 18,8 & 21,4 \\
\hline
\end{tabular}


Podawca, K. (2018). Analiza porównawcza temperatury powierzchniowej przegród w lokalach mieszkalnych w budynku wielorodzinnym z wielkiej płyty. Acta Sci. Pol. Architectura, 17 (1), 35-44. doi: 10.22630/ASPA.2018.17.1.4

Tabela 1 - cd. / Table 1 - cont.

\begin{tabular}{|c|c|c|c|c|}
\hline $5 \mathrm{~A}$ & płaszczyzna ściany - wall plane & \multirow{2}{*}{$\begin{array}{l}\text { wewn. - inside, sasiadująca } \mathrm{z} \text { łazienką - adjacent to the } \\
\text { bathroom }\end{array}$} & 21,6 & 21,9 \\
\hline $5 \mathrm{~B}$ & krawędź ściana-strop - wall-ceiling edge & & 20,0 & 21,2 \\
\hline & Pokój nr 1 - Room No 1 & Warunki wewnętrzne - Inside conditions & 20,0 & 20,4 \\
\hline $6 \mathrm{~A}$ & płaszczyzna ściany - wall plane & \multirow{2}{*}{$\begin{array}{l}\text { zewn. - outside } \\
\text { zach. - west. }\end{array}$} & 18,2 & 20,4 \\
\hline $6 \mathrm{~B}$ & krawędź ściana-strop - wall-ceiling edge & & 16,1 & 20,5 \\
\hline $7 \mathrm{~A}$ & płaszczyzna ściany - wall plane & \multirow{2}{*}{$\begin{array}{l}\text { wewn. - inside, sąsiadująca z WC - } \\
\text { adjacent to the toilets }\end{array}$} & 20,2 & 22,4 \\
\hline $7 \mathrm{~B}$ & krawędź ściana-strop - wall-ceiling edge & & 19,4 & 22,1 \\
\hline $8 \mathrm{~A}$ & ściana z oknem - wall with window & zewn. - outside, płn. - north & 16,5 & 20,0 \\
\hline $8 \mathrm{~B}$ & krawędź ściana-strop - wall-ceiling edge & stropodach - flat roof & 15,9 & 19,5 \\
\hline $9 \mathrm{~A}$ & płaszczyzna ściany - wall plane & zewn. - outside, zach. - west & 18,2 & 21,7 \\
\hline 9B & krawędź ściana-strop - wall-ceiling edge & stropodach - flat roof & 12,8 & 27,0 \\
\hline $10 \mathrm{~A}$ & płaszczyzna ściany - wall plane & wewn. - inside & 19,4 & 21,7 \\
\hline 10B & krawędź ściana-strop - wall-ceiling edge & stropodach - flat roof & 17,3 & 21,5 \\
\hline & Pokój nr 2 - Room No 2 & Warunki wewnętrzne - Inside conditions & 21,0 & 21,3 \\
\hline $11 \mathrm{~A}$ & płaszczyzna ściany - wall plane & wewn. - inside & 19,1 & 21,7 \\
\hline $11 \mathrm{~B}$ & krawędź ściana-strop - wall-ceiling edge & stropodach - flat roof & 17,9 & 22,1 \\
\hline $12 \mathrm{~A}$ & ściana z oknem - wall with window & zewn. - outside, płn. - north & 16,3 & 18,8 \\
\hline $12 \mathrm{~B}$ & krawędź ściana-strop - wall-ceiling edge & stropodach - flat roof & 14,0 & 19,7 \\
\hline $13 \mathrm{~A}$ & płaszczyzna ściany - wall plane & \multirow{2}{*}{$\begin{array}{l}\text { wewn. - inside, sąsiadująca z kuchnią - } \\
\text { adjacent to the kitchen }\end{array}$} & 19,2 & 21,6 \\
\hline $13 \mathrm{~B}$ & krawędź ściana-strop - wall-ceiling edge & & 18,4 & 21,9 \\
\hline & Kuchnia - Kitchen & Warunki wewnętrzne - Inside conditions & 21,6 & 19,8 \\
\hline $14 \mathrm{~A}$ & płaszczyzna ściany - wall plane & \multirow{2}{*}{$\begin{array}{l}\text { wewn. - inside, sassiadująca z pokojem nr } 2 \text { - } \\
\text { adjacent to the room No } 2\end{array}$} & 18,9 & 20,7 \\
\hline $14 \mathrm{~B}$ & krawędź ściana-strop - wall-ceiling edge & & 18,5 & 20,8 \\
\hline $15 \mathrm{~A}$ & ściana z oknem - wall with window & zewn. - outside, płn. - north & 14,4 & 18,7 \\
\hline $15 \mathrm{~B}$ & krawędź ściana-strop - wall-ceiling edge & stropodach - flat roof & 13,6 & 17,8 \\
\hline $16 \mathrm{~A}$ & płaszczyzna ściany - wall plane & \multirow{2}{*}{$\begin{array}{l}\text { wewn. - inside, sąsiadująca } \mathrm{z} \text { klatką schodową - } \\
\text { adjacent to the staircase }\end{array}$} & 18,0 & 20,4 \\
\hline $16 \mathrm{~B}$ & krawędź ściana-strop - wall-ceiling edge & & 16,6 & 20,5 \\
\hline & Lazienka - Bathroom & Warunki wewnętrzne - Inside conditions & 21,0 & 23,5 \\
\hline $17 \mathrm{~A}$ & płaszczyzna ściany - wall plane & \multirow{2}{*}{$\begin{array}{l}\text { zewn. - outside } \\
\text { zach. - west. }\end{array}$} & 21,5 & 26,1 \\
\hline $17 \mathrm{~B}$ & krawędź ściana-strop - wall-ceiling edge & & 18,5 & 26,3 \\
\hline & Przedpokój - Hall & Warunki wewnętrzne - Inside conditions & 20,2 & 20,4 \\
\hline $18 \mathrm{~A}$ & płaszczyzna ściany - wall plane & wewn. - inside & 20,1 & 21,3 \\
\hline 18B & krawędź ściana-strop - wall-ceiling edge & stropodach - flat roof & 19,2 & 21,5 \\
\hline
\end{tabular}

w salonie, granicząca z loggią (rys. 2). W innych przypadkach istnieją wyraźne różnice, przede wszystkim na ścianach zewnętrznych i przy krawędziach ściany ze stropem. (rys. 3 i 4 ).
Niebagatelną rolę w warunkach termicznych w poszczególnych pomieszczeniach odgrywają piony instalacyjne (rys. 5). W obiekcie II wpływają one na podwyższenie temperatury na płaszczyznach sąsiadujących 
Podawca, K. (2018). Analiza porównawcza temperatury powierzchniowej przegród w lokalach mieszkalnych w budynku wielorodzinnym z wielkiej płyty. Acta Sci. Pol. Architectura, 17 (1), 35-44. doi: 10.22630/ASPA.2018.17.1.4

a

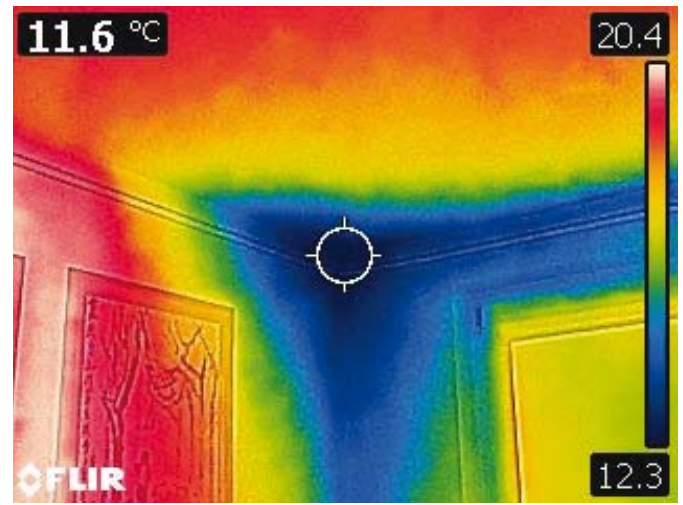

b

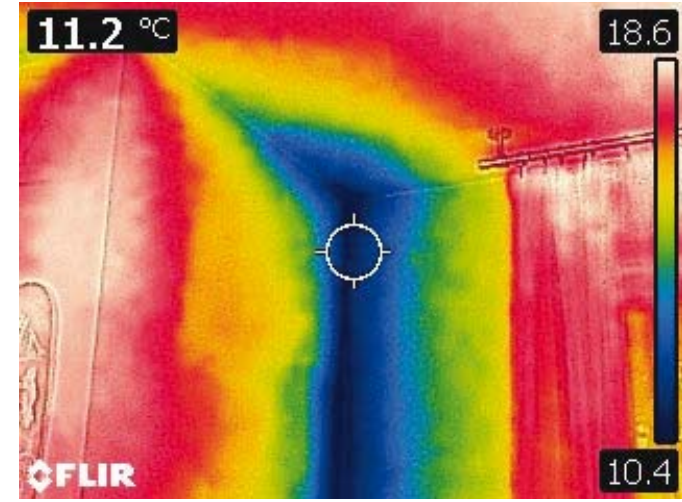

Rys. 2. Obraz termiczny ściany zewnętrznej, wnękowej w salonie - punkt 3C: a - obiekt I, b - obiekt II (opr. aut.)

Fig. 2. Thermogram of an external, recessed wall in the living room - point $3 \mathrm{C}: \mathrm{a}-$ object $\mathrm{I}, \mathrm{b}-$ object II (by the authors)

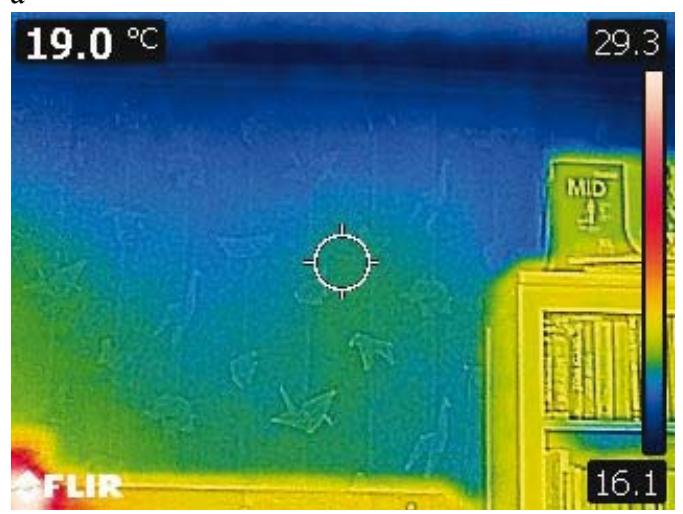

b

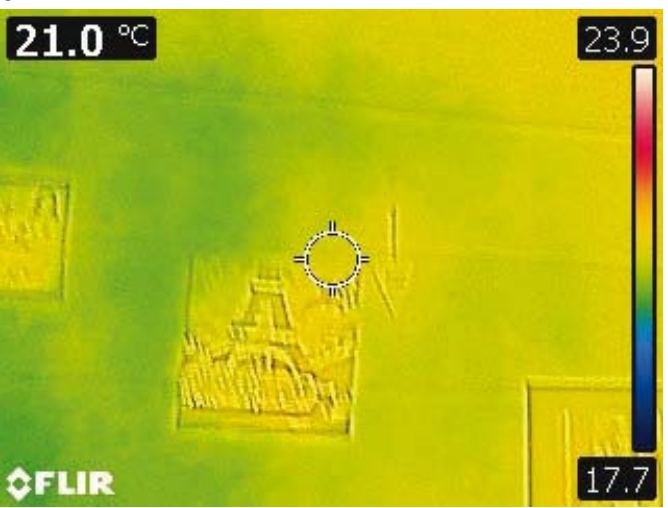

Rys. 3. Obraz termiczny ściany w pokoju nr 1 - punkty $6 \mathrm{~A}, 6 \mathrm{~B}$ : a - obiekt I, b - obiekt II (opr. aut.)

Fig. 3. Thermogram of wall in the room No 1 - points $6 \mathrm{~A}, 6 \mathrm{~B}$ : a - object I, b-object II (by the authors)
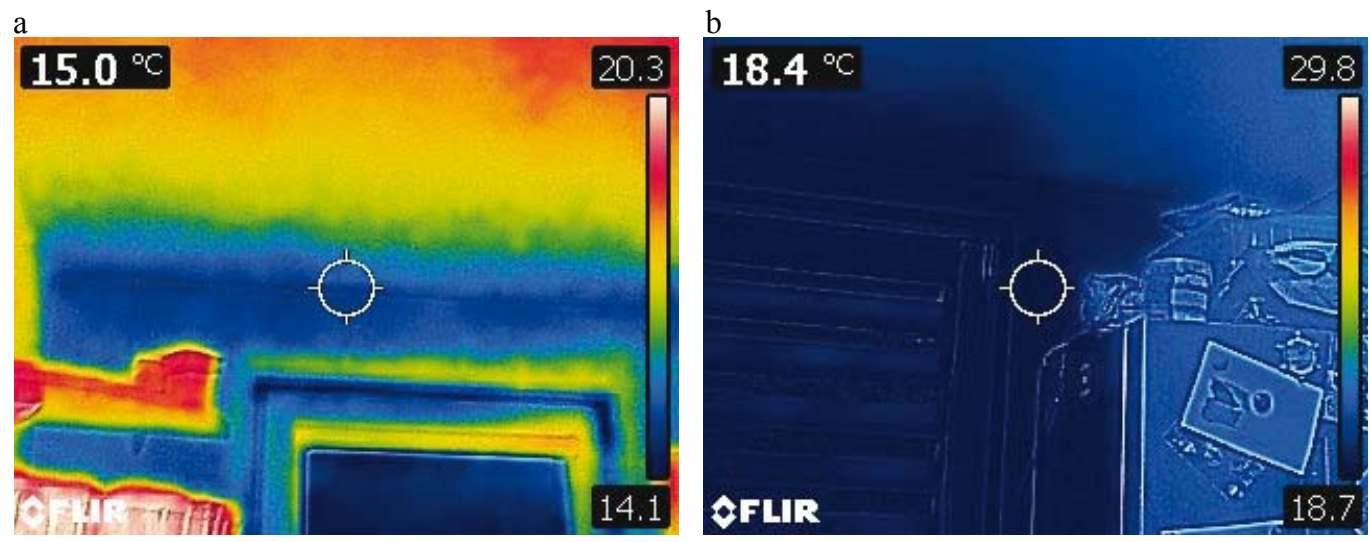

Rys. 4. Obraz termiczny ściany zewnętrznej w kuchni - punkt 15B: a - obiekt I, b - obiekt II (opr. aut.)

Fig. 4. Thermogram of an external wall in the kitchen - point 15B: a - object I, b - object II (by the authors) 
Podawca, K. (2018). Analiza porównawcza temperatury powierzchniowej przegród w lokalach mieszkalnych w budynku wielorodzinnym z wielkiej płyty. Acta Sci. Pol. Architectura, 17 (1), 35-44. doi: 10.22630/ASPA.2018.17.1.4

a

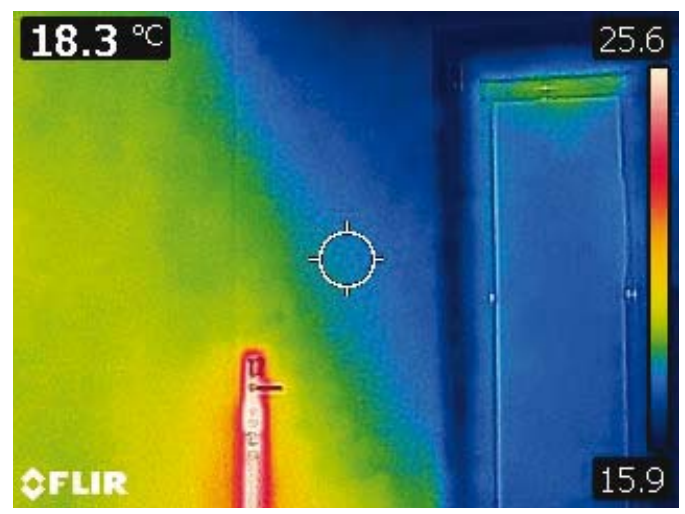

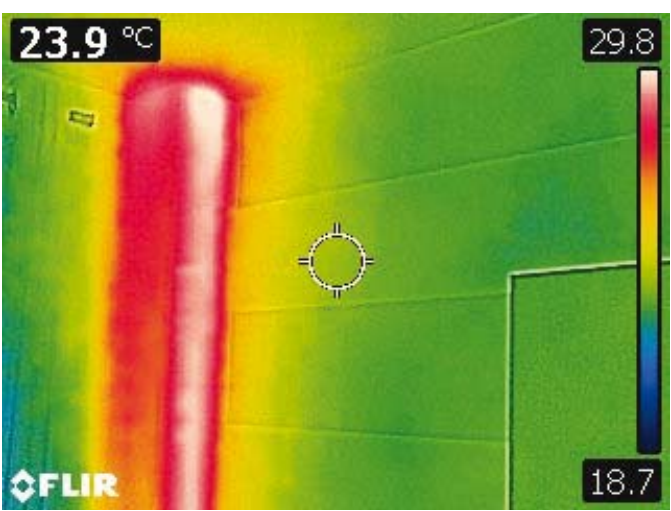

Rys. 5. Obraz termiczny ścian w pokoju nr 2 (pion c.o.) - punkty 12-13: a - obiekt I, b - obiekt II (opr. aut.)

Fig. 5. Thermogram of the wall in the room No 2 (c.o. instalation) - points 12-13: a - object I, b - object II (by the authors)

ścian. W obiekcie I piony kończą się na wysokości 1,20 m (ostatnia kondygnacja) i nie mają większego znaczenia przy ogrzewaniu pomieszczenia bez uruchomienia samych grzejników.

\section{ANALIZA WYNIKÓW}

Podstawy teoretyczne komfortu cieplnego wskazują na zależności pomiędzy temperaturą pomieszczenia a temperaturą przegród. Pomiary temperatury z charakterystycznych miejsc lokali odniesiono do obszarów odczuwania przez człowieka chłodu, gorąca lub przyjemności termicznej $\mathrm{w}$ danym pomieszczeniu. $Z$ wykresu na rysunku 6 jasno wynika, że w obiekcie I w wielu miejscach jest za chłodno. Taka sytuacja występuje tylko w przypadku jednego miejsca $\mathrm{w}$ obiekcie II. W odniesieniu do obiektu II jedynie w łazience można odnieść odczucie gorąca.

$\mathrm{W}$ tabeli 2 przedstawiono zestawienie różnic temperatury w stosunku do temperatury pomieszczenia, jak również różnic temperatury $\mathrm{w}$ analizowanych lokalach mieszkalnych w analogicznych miejscach.

Jak widać w obiekcie II temperatura przegród jest nieco wyższa od średniej temperatury powietrza. Zdecydowanie wynika to

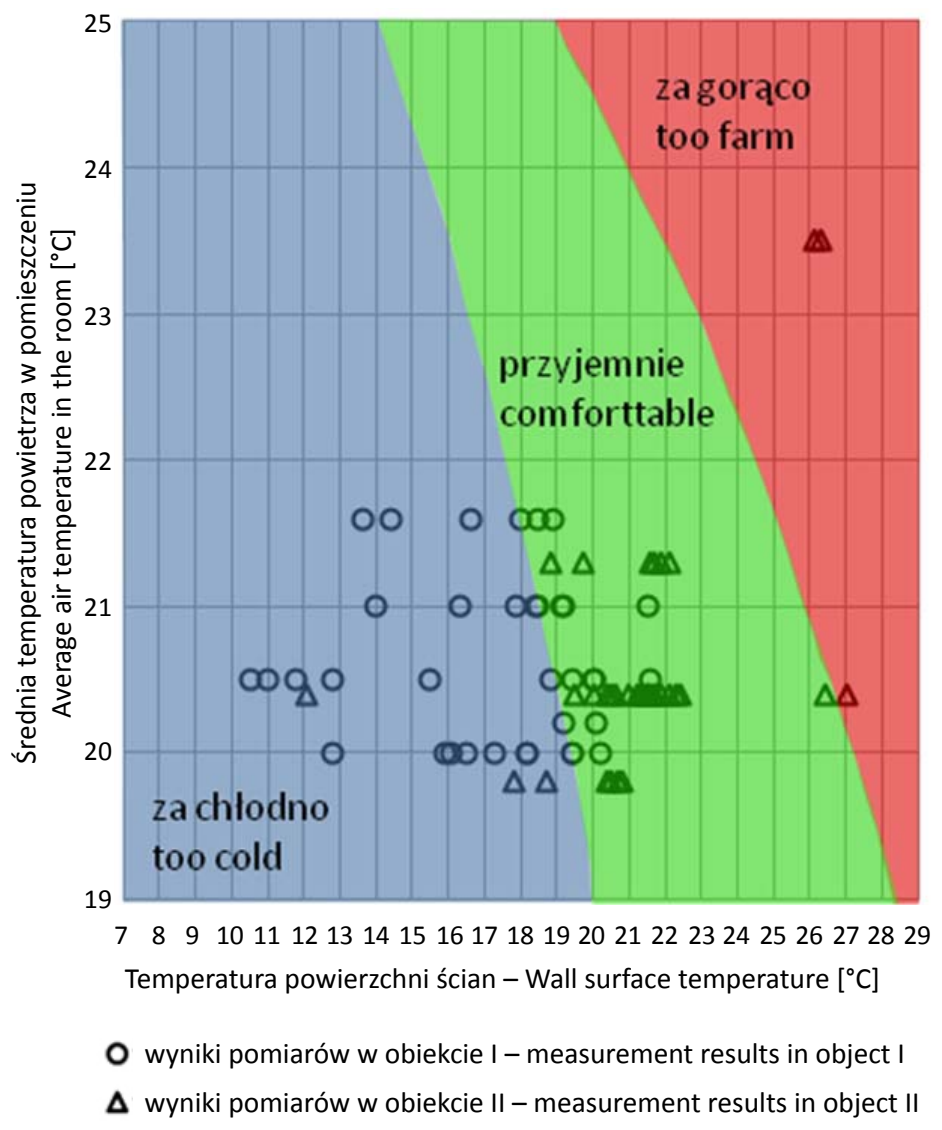

Rys. 6. Analiza porównawcza temperatury przegród w odniesieniu do odczucia cieplnego w pomieszczeniu (opr. aut.)

Fig. 6. Comparative analysis of baffle temperatures in relation to the thermal sensation in a room (by the authors) 
Podawca, K. (2018). Analiza porównawcza temperatury powierzchniowej przegród w lokalach mieszkalnych w budynku wielorodzinnym z wielkiej płyty. Acta Sci. Pol. Architectura, 17 (1), 35-44. doi: 10.22630/ASPA.2018.17.1.4

Tabela 2. Analiza porównawcza różnic temperatury w badanych lokalach mieszkalnych (opr. aut.)

Table 2. Comparative analysis of temperature differences in the analyzed apartments (by the authors)

\begin{tabular}{|c|c|c|c|c|}
\hline \multirow{3}{*}{$\begin{array}{l}\text { Rodzaj pomieszczenia } \\
\text { Type of room }\end{array}$} & \multirow{3}{*}{$\begin{array}{c}\begin{array}{c}\text { Miejsce pomiaru } \\
\text { Place of measurement }\end{array} \\
\mathrm{Nr}-\mathrm{No}\end{array}$} & \multicolumn{3}{|c|}{ Różnica temperatury - Temperature difference $\left[{ }^{\circ} \mathrm{C}\right]$} \\
\hline & & \multirow{2}{*}{$\frac{\Delta T_{\mathrm{I}}}{\text { Obiekt I }- \text { Object I }}$} & \multirow{2}{*}{$\begin{array}{c}\Delta T_{\mathrm{II}} \\
\text { Obiekt II }- \text { Object II }\end{array}$} & \multirow{2}{*}{$\Delta T_{R}$} \\
\hline & & & & \\
\hline \multirow{11}{*}{$\begin{array}{l}\text { Salon } \\
\text { Living room }\end{array}$} & $1 \mathrm{~A}$ & $-0,5$ & 1,2 & $-1,7$ \\
\hline & $1 \mathrm{~B}$ & -5 & 1,1 & $-6,1$ \\
\hline & $1-2 \mathrm{C}$ & $-7,7$ & 1,9 & $-9,6$ \\
\hline & $2 \mathrm{~A}$ & $-1,1$ & 0,6 & $-1,7$ \\
\hline & $2 \mathrm{~B}$ & -10 & 0,2 & $-10,2$ \\
\hline & $3 \mathrm{C}$ & $-8,7$ & $-8,3$ & $-0,4$ \\
\hline & $3-4 \mathrm{C}$ & $-9,5$ & 6 & $-15,5$ \\
\hline & $4 \mathrm{~A}$ & $-0,5$ & 1,1 & $-1,6$ \\
\hline & 4B & $-1,7$ & 1 & $-2,7$ \\
\hline & $5 \mathrm{~A}$ & 1,1 & 1,5 & $-0,4$ \\
\hline & $5 \mathrm{~B}$ & $-0,5$ & 0,8 & $-1,3$ \\
\hline \multirow{10}{*}{$\begin{array}{l}\text { Pokój nr } 1 \\
\text { Room No } 1\end{array}$} & $6 \mathrm{~A}$ & $-1,8$ & 0 & $-1,8$ \\
\hline & $6 \mathrm{~B}$ & $-3,9$ & 0,1 & -4 \\
\hline & $7 \mathrm{~A}$ & 0,2 & 2 & $-1,8$ \\
\hline & $7 \mathrm{~B}$ & $-0,6$ & 1,7 & $-2,3$ \\
\hline & $8 \mathrm{~A}$ & $-3,5$ & $-0,4$ & $-3,1$ \\
\hline & $8 \mathrm{~B}$ & $-4,1$ & $-0,9$ & $-3,2$ \\
\hline & $9 \mathrm{~A}$ & $-1,8$ & 1,3 & $-3,1$ \\
\hline & $9 \mathrm{~B}$ & $-7,2$ & 6,6 & $-13,8$ \\
\hline & $10 \mathrm{~A}$ & $-0,6$ & 1,3 & $-1,9$ \\
\hline & 10B & $-2,7$ & 1,1 & $-3,8$ \\
\hline \multirow{6}{*}{$\begin{array}{l}\text { Pokój nr } 2 \\
\text { Room No } 2\end{array}$} & $11 \mathrm{~A}$ & $-1,9$ & 0,4 & $-2,3$ \\
\hline & $11 \mathrm{~B}$ & $-3,1$ & 0,8 & $-3,9$ \\
\hline & $12 \mathrm{~A}$ & $-4,7$ & $-2,5$ & $-2,2$ \\
\hline & $12 \mathrm{~B}$ & -7 & $-1,6$ & $-5,4$ \\
\hline & $13 \mathrm{~A}$ & $-1,8$ & 0,3 & $-2,1$ \\
\hline & $13 \mathrm{~B}$ & $-2,6$ & 0,6 & $-3,2$ \\
\hline \multirow{6}{*}{$\begin{array}{l}\text { Kuchnia } \\
\text { Kitchen }\end{array}$} & $14 \mathrm{~A}$ & $-2,7$ & 0,9 & $-3,6$ \\
\hline & $14 \mathrm{~B}$ & $-3,1$ & 1 & $-4,1$ \\
\hline & $15 \mathrm{~A}$ & $-7,2$ & $-1,1$ & $-6,1$ \\
\hline & $15 \mathrm{~B}$ & -8 & -2 & -6 \\
\hline & $16 \mathrm{~A}$ & $-3,6$ & 0,6 & $-4,2$ \\
\hline & $16 \mathrm{~B}$ & -5 & 0,7 & $-5,7$ \\
\hline \multirow{2}{*}{ Łazienka - Bathroom } & $17 \mathrm{~A}$ & $-0,1$ & 2,6 & $-2,7$ \\
\hline & $17 \mathrm{~B}$ & $-3,1$ & 2,8 & $-5,9$ \\
\hline \multirow{2}{*}{ Przedpokój - Hall } & $18 \mathrm{~A}$ & $-0,1$ & 0,9 & -1 \\
\hline & $18 \mathrm{~B}$ & -1 & 1,1 & $-2,1$ \\
\hline
\end{tabular}


z faktu położenia lokalu mieszkalnego jako środkowego i ogrzewania mieszkań sąsiednich tak w układzie pionowym, jak i poziomym. Tylko w nielicznych przypadkach występuje sytuacja odwrotna. Niższą temperaturę pomierzono na ścianach zewnętrznych kuchni (brak grzejnika) oraz dwóch pokoi. Newralgicznym miejscem, świadczącym o błędzie konstrukcyjnym jest naroże ściany zewnętrznej wnęki przy loggi. W obiekcie I prawie każda temperatura powierzchniowa przegród jest niższa od temperatury pomieszczenia. Nie stanowi to jeszcze zagrożenia komfortu termicznego. Niestety jeśli rozpatrzy się te wielkości, to można stwierdzić, że różnice są zdecydowanie zbyt duże. Wynikiem jest odczuwanie chłodu w pomieszczeniach tego lokalu, a jednocześnie jest to dowód na złą izolacyjność termiczną przede wszystkim zewnętrznych przegród.

Wykonana seria obrazów termograficznych jednoznacznie wskazała miejsca o obniżonej temperaturze. W przypadku obiektu II jest to właściwie jedynie narożnik ściany wnękowej zewnętrznej w salonie, który sasiaduje z loggią. Pomimo ocieplenia budynku styropianem ubytek ciepła w tym miejscu jest bardzo duży, co może świadczyć o szczelinie pomiędzy płytami ściennymi, która nie została dodatkowo uszczelniona. W przypadku obiektu I można podać kilka newralgicznych miejsc pod kątem niskiej temperatury przegród, niezależnie od badanego pomieszczenia. Sa to: wszystkie krawędzie pomiędzy ścianami zewnętrznymi, płaszczyzny ścian zewnętrznych, płytowych, ocieplonych mała grubością wełny mineralnej z elewacją $\mathrm{z}$ blachy trapezowej oraz styki ścian wewnętrznych ze stropodachem.

\section{WNIOSKI I PODSUMOWANIE}

Reasumując wykonane badania i otrzymane wyniki, należy stwierdzić, że:

1. Komfort termiczny w obiekcie I jest zaburzony i trudno osiagalny (50\% punktów pomiarowych wykazuje za niską temperaturę).

2. W obiekcie II pod względem temperatury występuje odczucie przyjemności cieplnej ( $84 \%$ punktów pomiarowych leży w obszarze komfortu cieplnego), jedynie po trzy $(8 \%)$ dają poczucie chłodu - kuchnia z otwartym oknem i brakiem grzejnika i trzy $(8 \%)$ poczucie gorąca - łazienka.
3. W obiekcie II wykonano termomodernizację, która zdecydowanie zmniejszyła współczynnik przenikania ciepła $U=0,227$, uwzględniając następujące warstwy od wewnątrz: tynk cementowo-wapienny $2 \mathrm{~cm}$, płyta warstwowa prefabrykowana $26 \mathrm{~cm}$, styropian $\mathrm{o} \lambda=$ $=0,031$, tynk mineralny cienkowarstwowy $2-3 \mathrm{~mm}$ ).

4. W obiekcie I nie było wykonanej termomodernizacji, dlatego współczynnik $U$ ściany szczytowej wynosi 0,646 , na co składają się opory następujących warstw od wewnątrz: tynk cementowo-wapienny $2 \mathrm{~cm}$, płyta warstwowa prefabrykowana $26 \mathrm{~cm}$, wełna mineralna $6 \mathrm{~cm}$, blacha trapezowa.

5. W obiekcie I w zasadzie przy każdej krawędzi i narożniku ściany zewnętrznej i stropodachu występują straty ciepła, które wskazują na błędy konstrukcyjne połączenia płyt ściennych i stropowych oraz złego funkcjonowania ocieplenia $\mathrm{z}$ wełny mineralnej.

6. Prawdopodobne błędy izolacyjno-konstrukcyjne przekładają się na koszty ogrzewania analizowanych lokali, które obrazować mogą różnice w jednostkach na podzielnikach ciepła w 2017 roku w poszczególnych pomieszczeniach (obiekt I: salon - 1857, pokój nr $1-1660$, pokój nr $2-420$; obiekt II: salon -109 , pokój nr 1 -149, pokój nr 2 -11). Uwzględniając nawet współczynniki korygujące, widać, że różnica jest ponad 10-krotna.

Podsumowując, należy podkreślić, że na podstawie zaprezentowanych przykładów można założyć, że obiekty budowlane spółdzielni Górczewska w Warszawie wymagają termomodernizacji. Dawne ocieplenia ścian zewnętrznych i szczytowych małą grubością wełny mineralnej obłożonej blachą trapezową całkowicie nie spełniają zadań izolacyjnych, podobnie jak złe ocieplenie wentylowanych stropodachów. Wykonana analiza nie potwierdziła opinii jakoby usytuowanie pomieszczeń na najwyższej, najniższej lub środkowej kondygnacji oddziałuje w nieznacznym stopniu na wartości liczbowe rozkładu temperatury (Śliwowski, 2010). Wręcz przeciwnie, różnice w komforcie cieplnym w mieszkaniach na środkowych kondygnacjach $\mathrm{w}$ budynkach $\mathrm{z}$ wykonaną termomodernizacją $\mathrm{w}$ porównaniu $\mathrm{z}$ lokalami na ostatnich piętrach $\mathrm{w}$ obiektach nierewitalizowanych są bardzo wyraźne. Zapewnienie takiego komfortu w mieszkaniach na ostatnich kondygnacjach odbywa się kosztem intensywnego ogrzewania i wysokich opłat za centralne ogrzewanie. 
Podawca, K. (2018). Analiza porównawcza temperatury powierzchniowej przegród w lokalach mieszkalnych w budynku wielorodzinnym z wielkiej płyty. Acta Sci. Pol. Architectura, 17 (1), 35-44. doi: 10.22630/ASPA.2018.17.1.4

\section{PIŚMIENNICTWO}

Alsabry, A. (2010). Fizyka budowli dla doradców i audytorów energetycznych, Zielona Góra: Oficyna Wydawnicza Uniwersytetu Zielonogórskiego.

Alsabry, A., Mrówczyńska, M., Bazan-Krzywoszańska, A. i Skiba, M. (2016). Potencjał termomodernizacji osiedli z wielkiej płyty na przykładzie budynków mieszkalnych w Zielonej Górze. Materiały Budowlane, 8, $84-85$.

Bohojło, A. (2010). Wyznaczanie parametrów komfortu cieplnego w pomieszczeniu mieszkalnym. Civil and Environmental Engineering, 1, 11-16.

Dylla, A. (2015). Fizyka cieplna budowli w praktyce - obliczenia cieplno-wilgotnościowe. Warszawa: Wydawnictwo Naukowe PWN.

Kaliszuk-Wietecka, A. (2017). Budownictwo zrównoważone - wybrane zagadnienia z fizyki budowli. Warszawa: Wydawnictwo Naukowe PWN.

Knyziak, P. (2017). Nieprawidłowe użytkowanie i modernizowanie głównymi zagrożeniami trwałości budynków z wielkiej płyty. W M. Kaszyńska (red.), Awarie budowlane. Zapobieganie, diagnostyka, naprawy, rekonstrukcje (strony 283-294). Szczecin: Zachodniopomorski Uniwersytet Technologiczny.

Kukla, K. (2015). Zastosowanie kamery termowizyjnej do identyfikacji wad izolacji termicznej budynków. Opole: Termo-Control. Pobrano z lokalizacji: http://termo-control.pl/czytelnia

Ostańska, A. (2016). Wielka ptyta. Analiza skuteczności podwyższania efektywności energetycznej. Warszawa: Wydawnictwo Naukowe PWN.
PN-EN 13187:2001. Właściwości cieplne budynku - jakościowa detekcja wad cieplnych w obudowie budynku. Metoda podczerwieni.

PN-EN ISO 6946:2008. Komponenty budowlane i elementy budynku. Opór cieplny i współczynnik przenikania ciepła. Metoda obliczania.

Runkiewicz, L., Szudrowicz, B., Geryło, R., Szulc, J. i Sieczkowski, J. (2014). Diagnostyka i modernizacja budynków wielkopłytowych. Część 2. Przeglad Budowlany, 9, 20-26.

Rymarczyk, Z., Dzierzgowski, M. i Strzeszewski, M. (2005). Zastosowanie termografii do jakościowej oceny ochrony cieplnej budynków. W Z. Popiołek (red.). Energooszczędne kształtowanie środowiska wewnętrznego. Gliwice: Politechnika Śląska.

Sawicki, J. (2007). Co dalej z wielką płytą? Izolacje, VII/ /VIII, 70-72.

Sobczak-Piąstka, J. i Podhorecki, A. (2014). Problemy diagnozowania stanu technicznego i modernizacji budynków $\mathrm{z}$ wielkiej płyty. Inżynier Budownictwa, 2, 78-86.

Sudoł-Szopińska, I. i Chojnacka, A. (2007). Określenie warunków komfortu termicznego w pomieszczeniach za pomocą wskaźników PMV i PPD. Bezpieczeństwo Pracy, 5, 19-23.

Śliwowski, L. (2010). Mikroklimat wnętrz. W P. Klemm (red.). Budownictwo ogólne - fizyka budowli. Tom 2. Warszawa: Wydawnictwo Arkady.

Wójtowicz, M. (2011). Możliwość awarii warstwowych ścian zewnętrznych budynków wielkopłytowych - problem realny czy sensacja medialna? W XXV Konferencja Naukowo-Techniczna „Awarie budowlane” (strony 533-542). Szczecin-Międzyzdroje.

\title{
COMPARATIVE ANALYSIS OF SURFACE TEMPERATURES LISTEN TO RESIDENTIAL BUILDINGS IN A MULTI-FRAMEWORK BUILDING WITH A GREAT PLATE
}

\begin{abstract}
The article presents studies on temperatures emitted by building partitions in a multi-family building constructed in the technology of a large slab. Two dwellings with the same functional arrangement, but with a different location in the body of the object were selected for the study. The measurements showed significant differences in the temperature, especially in sensitive places, between the middle apartment on the first floor and the residential apartment on the top floor. The analysis clearly showed the necessity of thermomodernization of objects from the large slab, as well as significant differences in obtaining thermal comfort in residential premises located on different storeys and with or without gable walls.
\end{abstract}

Key words: multi-family residential building, thermography, great plate, thermal comfort 